\title{
Forecasting Exports and Imports by using Autoregressive (AR) with Seasonal Dummies and Box-Jenkins Approaches: A Case of Pakistan
}

\author{
Saghir Pervaiz Ghauri', Rizwan Raheem Ahmed ${ }^{2}$, Dalia Streimikiene ${ }^{3}$, Justas Streimikis ${ }^{4,5}$ \\ ${ }^{1}$ Department of Economics, the Jinnah University for Women \\ Block-5, Nazimabad, Karachi-74600, Pakistan \\ E-mail.saghir.ghauri@gmail.com \\ ${ }^{2}$ Faculty of Management Sciences, Indus University \\ Block-17, Gulshan, Karachi-75300, Pakistan \\ E-mail.rizwanraheemahmed@gmail.com
}

${ }^{3}$ Lithuanian Sports University, Institute of Sport Science and Innovations

Sporto str. 6, Kaunas, Lithuania

E-mail.dalia.streimikiene@lei.lt

${ }^{4}$ Lithuanian Institute of Agrarian Economics

A. Vivulskio g. 4A-13, 03220 Vilnius, Lithuania

${ }^{5}$ University of Economics and Human Science in Warsaw

Okopowa 59, 01-043 Warsaw, Poland

E-mail.jutas.streimikis@gmail.com

cross $^{\text {ref }}$ http://dx.doi.org/10.5755/j01.ee.31.3.25323

This research aims to evaluate two econometric models to forecast imports and exports for the financial year (FY) 2020. For this purpose, we used the annual exports and imports data of Pakistan from FY2002 to FY2019. Thus, in this regard, we employed, and compared the results of two econometrics models such as Box Jenkins or Autoregressive Integrated Moving Average (ARIMA), and Auto-Regressive (AR) with seasonal dummies. For examining the precision of forecasting, we employed mean absolute error and root mean square error approaches. The findings of Root Mean Square Error (RMSE) and Mean Absolute Error (MAE) reveal that the ARIMA or Box Jenkins approach provides better accuracy of the forecast for the exports as compared to the AR model with dummies. However, Auto-Regressive (AR) model has demonstrated more precision for the imports as compared to the Box Jenkins model. Hence, the projected forecasting for the growth of export is $1.87 \%$ for the FY2020 and projected forecasting for the import demonstrates a negative variation of $-1.61 \%$ for the FY2020. The findings of the undertaken study recommend the policymakers of Pakistan to take corrective measures to increase exports and to prevent the country from the trade deficit. The policymakers of Pakistan should give more incentives to the exporters and decrease the cost of doing business to be more competitive than the regional economies such as India, Bangladesh, and China.

Keywords: Forecasting; Imports \& Exports; ARIMA Model; Box Jenkins Approach; AR-Model with Seasonal Dummies; RMSE Model; MAE Model.

\section{Introduction}

Trade deficit plays a significant part in the formation of both fiscal and monetary policies of a country, export is a vibrant constituent of the GDP of any country, and export has a direct influence on the balance of payment, the creation of employment, and economic growth. Several factors exhibit the export performance of any country; these factors are divided into supply and demand relatedfactors (Sokolov-Mladenovic, Milovancevic, Mladenovic, \& Alizamir, 2016; Ersen, Akyuz, \& Bayram, 2019). The capacity of the trading partners such as gross domestic product (GDP), exportable prices, competitor's prices, exchange rate, policy matters, and political stability are the demand-side factors. However, for the supply side, determinants comprise wage rate, relative prices, exchange rates, imports, world prices, world income, and domestic production capacity generally measured through GDP (Sharma, 2019; Kankal \& Uzlu, 2017). Both demand and supply sides are essential, and previous data have demonstrated the importance of these factors such as Kaur and Rakshit (2019), Kitworawut and Rungreunganun (2019), Tabrizi and Sancar (2017), and Ahmed, Ghauri, Vveinhardt, and Streimikiene (2018). In terms of purchasing power parity, Pakistan has the $24^{\text {th }}$ rank in the world's economy. However, the $42^{\text {nd }}$ biggest economy in terms of nominal GDP that made $\$ 1357$ per capita in 2019 . In terms of Pakistani Rupee, the total GDP of Pakistan was PKR38558.8 billion for the FY2019, and it is estimated at approx. PKR43585 billion for the FY2020. The total exports were registered at $\$ 23041$ million for the FY2019. However, it was less than $-0.88 \%$ as compared to FY2018. 
Similarly, the imports were $\$ 55169$ million, which shows a negative variation of $-9.70 \%$ as compared to FY2018. The per capita income was $\$ 1497.30$ in FY2019; however, it was $\$ 1652$ for the FY2018. The inflation of FY2019 was $-7 \%$, the reserves were $\$ 14.477$ billion for the same fiscal year, however, the trade deficit was $-11.9 \%$ as a percent of GDP was recorded for the FY2019 ${ }^{1}$. Foreign remittances are a significant part of Pakistan's GDP, and it had a 9.7\% growth in the fiscal year 2019 (Mehmood et al., 2020). The balance of payment and trade deficit has always been a burning question for Pakistan's economy and also hampered other macroeconomic indicators. Pakistan's exports have been declining continuously. Data shows that Pakistan had \$25,171 million in FY2014; however, it has dropped down to $\$ 23,041$ million for FY2019. Though the imports have been continuously rising, the total imports for the FY2019 were $\$ 55,169$ million. Thus, it is more than double the exports, which shows the vulnerability of trade deficit and balance of payment (Mehmood et al., 2020). According to Azgun and Servinc (2010), Chen (2009), Dokovic, Muncan, and Paunovic (2019), Kogid et al. (2011), Alam, Uddin, and Taufique (2009), and Sharma (2019), the exports and imports have exerted a significant and sustainable influence on economic growth of different economies of the world. Thus, based on the previous literature, we tried to construct a suitable econometrics model to predict the exports and imports values in the case of the Pakistani economy. The crude oil has a significant chunk in Pakistan's imports; other imports include automobiles, defense equipment, computers, industrial machinery, medicines, electronics, and consumer appliances, etc. However, the major exports comprise textile goods, Rice, Cement, leather goods, Fighter Jets, and Carpets, etc. (Alam et al., 2009).

The development of effective models for the forecasting of imports and export flows for any country is driven by the importance of trade balance for both national accounts and external transactions. The exports are one of the significant apparatuses to offset the trade deficit, and source of foreign currency arrangement, which is a direct determinant of the foreign reserves of the central bank. The private agents' decisions to consume imported goods, and to export their products to the international markets, depending on their financial potential and their competitiveness. The foreign trade is also an essential component of the GDP developments. The existence of trade deficits for a relatively long period might, under some circumstances, be a risk factor for future growth prospects.

On the other hand, the gaps might represent the process of capital accumulation and, through intensified investments, increase the growth potential of a country. In all cases, developing an alternative instrument for short-run export and import forecasting is justified by the need for providing better analysis and forming more accurate expectations about the economic development of the country. Bridging the gap between exports and imports is a challenge to the national trade policymakers of any country (Mehmood et al., 2020). Thus, the econometric time-series

\footnotetext{
1 Finance Division, Government of Pakistan. Highlights: Pakistan Economic Survey 2018-19, Islamabad, 2019.
}

modeling is an essential tool to forecast the sustainable exports and imports of the country.

This research paper aims to examine Pakistan's foreign trade, aimed at projecting the export and import dynamics of Pakistan through a useful forecasting model. It is motivated by the need for producing a reliable assessment of the foreign trade development of the country and allowing better forecasting of other balance of payments components as well for future planning. Logically the forecasting is preceded by an analysis of the relations between the macroeconomic processes. The forecasting objective of the study restricts econometric specifications to include primarily explanatory factors for which external assumptions on their likely future sustainable development are available (Muncan \& Paunovic, 2019). The relatively long period of transition in Pakistan and the associated structural changes shorten the available time series and raise specific econometric issues. These characteristics limit the applicability and reliability of standard stationarity tests, and at the same time, hinder the assessment of a long-run relationship, thus naturally restricting the forecasting horizon up to one year ahead. Therefore, this study is carried out to bridge this gap.

\section{Theoretical Grounds with Empirical Studies}

The contemporary foreign trade theory encompasses a wide variety of research problems, analyzes the relations and causality between numbers of economic processes, and provides an ample field for empirical work. A large part of the traditional theory is focused on the causes of foreign trade development and its consequences. The increasingly integrated world and the trend towards higher openness and interdependence between the countries led towards the incorporation of open economy features in almost all models for macroeconomic analysis and forecasting. In empirical work, however, there is always a trade-off between theoretical consistency and practical relevance. As the approach followed in the current research effort is one of econometric estimation of the existing economic relations, the balance between theory and empirical relevance is in favour of the latter. The classical international trade theory includes the Ricardian, technology-based technique, and the Heckscher-Ohlin factor endowments approach. More recently, the foreign trade factors and driving forces were expanded to include increasing returns to scale, monopolistic competition, preference for variety, market failures, while the predicted specialization is one of intra-industry trade. Gravity and endogenous growth models also contributed to the theoretical advances along with the theory of competitive advantage. Examples of empirical foreign trade studies, relevant to the presented work, include Ersen et al. (2019), Kitworawut and Rungreunganun (2019), SokolovMladenovic et al. (2016), Kankal and Uzlu (2017), and Anderton, Baltagi, Skudelni, and Sousa (2005) among others. The authors of the first study model the Canadian foreign trade flows as a function of the agents' decisions in solving a dynamic optimization problem. The desired level 
of imports in their setup is a direct task of local demand, and compare prices and solutions of the problem leads to a Euler equation for imports. The coefficients of this equation are estimated in two steps, with co-integration techniques at the first and generalized method of moments (GMM) at the second. The estimated import elasticity vis-à-vis domestic demand and comparative prices are respectively 1.5 and 0.5 . Although the technique provides micro-foundations for the empirical estimation of macroeconomic relations, the co-integration and GMM methods are practically inapplicable to small samples.

An example of an alternative econometric approach is provided by Anderton et al. (2005), who use the three-stage least squares (3SLS) system estimator for analysing the import demand of nine Euro system countries. Chou, Chu, and Liang (2008) have analysed the association between imports and exports of Taiwan; they employed a modified regression formula for forecasting purposes. They compared the accuracy of traditional regression and modified regression models in forecasting; they used numerous macroeconomic indicators such as population, exports, GNP, agricultural GDP, GDP, Per capita GNP, services GDP, and industrial GDP, etc. X-12-ARIMA approach has been used to analyse, and predict the possible seasonality of oil imports in the case of China (Zhou \& Dong, 2012). Yue (2010) has carried out important research in Cote d'Ivoire to forecast the import demands for the period 1970 to 2007. Researchers employed the cointegration approach for forecasting and incorporated four indicators, including comparative prices, final consumption expenses, export expenses, and investment spending. Narayan P.K., Narayan S., and Prasad (2008) have forecasted exports and imports (2003-2020) in the case of Fiji's economy by using autoregressive-moving average with explanatory (ARMAX) model. For the forecasting in the growth of imports from major developed economies, Keck, Raubold, and Truppia (2009) have developed specialised econometric modelling. According to Sahu and Mishra (2013), the autoregressive integrated moving average (ARIMA) has to be happening more effective to forecast the export and import of spices, production and cultivated area in the case of the Indian and Chinese economies.

Similarly, Shu, Nguyen, Hsu, Lu, and Huang (2014) have adopted the same approach (ARIMA), Grey model, and combined Fourier techniques for projecting the cargo output at the seaport. Zhang and Zhao (2013) have developed a mathematical approach to grim forecasting, and they took collective exports and imports trade of Ningbo seaport for the period of 2004 to 2011 . In the case of the South African economy, Kargbo (2007) have employed alternative techniques to forecast exports and imports of agricultural goods. They have incorporated five models for this purpose, for instance, the Engle-Granger single equation model, VAR model, VECM, and Box Jenkins approach, and exponential smoothing model. However, Farinelli, Carter, Cynthia-Lin, and Sumner (2009) have used ordinary least squares (OLS), they took quarterly data and transformed data series into the natural log. They have taken numerous macroeconomic indicators such as rate of exchange, GDP, lagged quantity of ethanol, crude oil prices, tend, import tariffs, and forecasted the import demand of ethanol from 1997 to 2007 in case of the Brazilian economy.

Correspondingly, Khan (2011) has selected a suitable approach for forecasting models for the imports of the Bangladeshi economy. Though, In the Pakistani context, Ghafoor, Abedullah, Khokhar, and Hanif (2005) have studied three indicators of the wheat economy, such as imports, production, and procurement for the period of 1970 to 2003. They examined the growth rates and forecasted these three indicators of the wheat economy; they also ascertained the association amid wheat imports and government procurement. In the case of the Chinese economy, Fukumoto (2012) examined three fundamental categories of goods, such as transitional inputs, capital goods, and finished consumer goods. They have studied and forecasted the effect of these three classes on disaggregated import demand function, and their influence on the economic growth of a country. There are recent attempts to create hybrid models by combining autoregressive forecasting techniques by integrating them with other approaches like Bayesian artificial neural networks (Yucesan, Gul, \& Celik, 2017; Kankal \& Uzru, 2017; Zeng Y.R., Zeng Y., Choi, \& Wang, 2017; Urrutia, Abdul, \& Atienza, 2019; Sokolov-Mladenovic et al., 2016; Alam, 2019) or with other techniques (Wang, Chau, Xu, \& Chen, 2015; Mladenovic, Lepojevi, \& VJankovi-Milic, 2016).

\section{Materials and Methods}

The data for the undertaken study has been taken from July 2002 to June 2019. The export and import data is obtained from the various volumes of statistical bulletins of the Pakistan Bureau of Statistics (PBS). For the analysis purposes, we used a natural log for both series. For the forecasting purposes, the exponential smoothing approach is more suitable that avoids assumptions regarding the correlation among the consecutive values of time series. Though, if researchers desire to create prediction intervals in forecasting, then the prediction breaks require forecast errors that would be uncorrelated and normally distributed with constant variance and mean zero. The data series should be transformed into stationary before applying MA, AR, and ARIMA or Box Jenkins approaches (Mehmood et al., 2020; Kitworawut \& Rungreunganun, 2019). Since we used time-series data for this research, thus, Philips-Perron (1988), Augmented Dickey-Fuller (1979, 1981) for the stationarity, and Box Jenkins or ARIMA approach, and Auto-Regressive (AR) with seasonal dummies have been employed for the forecasting of import and export.

\section{Philips-Perron and Augmented Dickey-Fuller Models}

The first objective of this research is to examine the stationarity of the data; for this purpose, we employed Augmented Dickey-Fuller (1979, 1981). Equation (1) is the simplified form of this technique:

$$
\Delta y_{t}=\alpha_{0}+\alpha_{1} y_{t-1}+\sum_{i=1}^{n} \alpha \Delta y_{t}+e_{t}
$$


Equation (1) comprises of data series ' $y$ ' in period ' $t$ ', however, ' $n$ ' is denoted for an optimum number of lags, ' $\alpha_{0}{ }^{6}$ is represented for a constant value, and ' $\mathrm{e}$ ' is referred for a white noise error. Though Philips and Perron (1988) have presented another robust test for the stationarity, and Equation (2) is the mathematical representation of this test:

$$
\Delta y_{t}=\alpha_{0}+\alpha_{1} y_{t-1}+e_{t}
$$

Equation (2) comprises of data series ' $y$ ' in period ' $t$ ', however, ' $\alpha_{0}$ ' is signified for a constant value, and ' $e$ ' is referred for a white noise error.

\section{Autoregressive (AR) Model}

In econometric time series, the random walk model is an important technique, and this is also known as the Autoregressive (AR) model or simply an $\mathrm{AR}(1)$ process. Equation (3) is the simplest form of this technique:

$$
y_{t}=y_{t-1}+u_{t}
$$

Equation (3) of the model is known as the non-drifted random walk model. If the constant value is added in Equation (3), then it will be converted into a random walk model with drift. If $\mathrm{AR}(p)$ process is stationary that evaluates characteristic modelling equation roots, and $\phi(L)^{-1}$ converges to zero then $\operatorname{AR}(p)$ process is become stationary with lag operator notation and could be written as Equation (4):

$$
\begin{aligned}
& \phi(L) y_{t}=u_{t} \\
& y_{t}=\phi(L)^{-1} u_{t}
\end{aligned}
$$

Autocorrelations converge into zero if we increase the lag length, and Auto-regressive AR ( $p$ ) approach become stationary, then Equation (5) demonstrates the roots of characteristics as:

$$
1-\phi_{1} z-\phi_{2} z^{2}-\ldots-\phi_{p} z^{p}=0
$$

In Equation (5), the roots of characteristics lie outside the circle, and then it is $>1$. Moreover, it is essential to comprehend that the random walk model's roots placed on the unit circle. Thus, this condition is referred to as a nonstationary procedure of random walk, and Equation (6) is the mathematical representation of this form:

$$
\begin{aligned}
& y_{t}=y_{t-1}+u_{t} \\
& y_{t}=L y_{t}+u_{t} \\
& y_{t}(1-L)=u_{t} \\
& 1-z=0 \\
& z=1
\end{aligned}
$$

In Equation (7), the characteristic equation called ' $1-z$ ', and root $(z)$ place on the unit circle. The variance and mean are other characteristics of $\operatorname{AR}(p)$ then $\operatorname{AR}(1)$ procedure could be written as Equation (8):

$$
E\left(y_{t}\right)=\frac{\mu}{1-\phi_{1}}, \operatorname{var}\left(y_{t}\right)=\frac{\sigma^{2}}{\left(1-\phi_{1}^{2}\right)}
$$

\section{Auto-Regressive Moving Average (ARMA) Technique}

For future forecasting purposes in any time series, we employed the ARMA model. The ARMA technique comprises of autoregressive $\operatorname{AR}(p)$ and moving average MA $(q)$. Thus, for orders ' $p$ ', the $\operatorname{AR}(p)$ could be expressed as Equation (9):

$$
X_{t}=c+\sum_{i=1}^{p} \phi_{i} X_{t-i}+\varepsilon_{t}
$$

The moving average $\operatorname{MA}(q)$ equation for ' $q$ ' orders can be expressed as follows in Equation (10):

$$
X_{t}=\mu+\varepsilon_{t}+\sum_{i=1}^{q} \theta_{i} \varepsilon_{t-i}
$$

Combining the ARMA $(p, q)$ model, we will get:

$$
X_{t}=c+\varepsilon_{t}+\sum_{i=1}^{p} \phi_{i} X_{t-i}+\sum_{i=1}^{q} \theta_{i} \varepsilon_{t-i}
$$

In Equation (11), the white noise error $\varepsilon_{t}$ is usually presumed to be an independent and distributed uniformly with random variables $(i, i, d)$ assessed by the normal distribution with zero mean: $\varepsilon_{t} \sim \mathrm{N}\left(0, \sigma^{2}\right)$ and variance as $\sigma^{2}$.

\section{Auto-Regressive Integrated Moving Average (ARIMA) Technique}

The ARIMA is the generalization form of the ARMA approach. For the forecasting of points in any time series, we used ARIMA, the benefit of this technique is to use even for the non-stationary data because it diminishes the nonstationarity. Moreover, it is a data-oriented approach that finds out the autocorrelations. This model has also definite in terms of Lag operator in some textbooks. Thus, the model AR $(p)$ could be written as follows model:

$$
\varepsilon_{t}=\left(1-\sum_{i=1}^{p} \phi_{i} L^{i}\right) X_{t}=\phi(L) X_{t}
$$

where in Equation (12) ' $\phi$ 'is represented for the polynomial function as: $\phi(L)=1-\sum_{i=1}^{p} \phi_{i} L^{i}$

The MA $(q)$ model is given by as in Equation (13):

$$
X_{t}=\left(1+\sum_{i=1}^{q} \theta_{i} L^{i}\right) \varepsilon_{t}=\theta(L) \varepsilon_{t}
$$

where in Equation (13) ' $\theta$ ' is denoted for the polynomial function: $\theta(L)=1+\sum_{i=1}^{q} \theta_{i} L^{i}$

Finally, we can write the combined model of ARMA ( $p$, $q$ ) as follows in Equation (14):

$$
\left(1-\sum_{i=1}^{p} \phi_{i} L^{i}\right) X_{t}=\left(1+\sum_{i=1}^{q} \theta_{i} L^{i}\right) \varepsilon_{t}
$$
(15):

OR more concisely could be expressed as Equation

$$
\begin{aligned}
\phi(L) X_{t}= & \theta(L) \varepsilon_{t} \\
& \frac{\phi(L)}{\theta(L)} X_{t}=\varepsilon_{t}
\end{aligned}
$$




\section{Box Jenkins Approach}

Box, Jenkins, and Reinsel (1994), and Box and Jenkins (1976) have incorporated different bonds of autoregression coefficients. This approach permits all the polynomial functions that involve a lag operator to emerge in an associated practice during the process. Hence, the following form of ARIMA could be expressed as already discussed in Equation (14):

$$
\left(1-\sum_{i=1}^{p} \phi_{i} L^{i}\right) X_{t}=\left(1+\sum_{i=1}^{q} \theta_{i} L^{i}\right) \varepsilon_{t}
$$

Further, if we fixed $\phi_{0}=\theta_{0}=1$, then the following model will be extracted as Equation (16):

$$
\sum_{i=0}^{p} \phi_{i} L^{i} X_{t}=\sum_{i=0}^{q} \theta_{i} L^{i} \varepsilon_{t}
$$

$\operatorname{ARIMA}(p, q, d)$ or Box Jenkins is a non-seasonal technique in which ' $p$ '; ' $q$ ' and ' $d$ ' are non-negative numbers. Thus, Equation (17) is the mathematical model of this technique:

$$
\left(1-\sum_{i=1}^{p} \phi_{i} L^{i}\right)(1-L)^{d} X_{t}=\left(1+\sum_{i=1}^{q} \theta_{i} L^{i}\right) \varepsilon_{t}
$$

\section{Forecasting Error}

As there are always errors in forecasting, therefore, to ensure the maximum accuracy and measure that error, we use Mean Absolute Error (MAE) and Root Mean Square Error (RMSE). Equation (18) and Equation (19) are the mathematical models of MAE and RMSE:

$$
\begin{array}{r}
M A E=\frac{\sum_{i=1}^{n}\left|x_{i}-\hat{x}_{i}\right|}{n} \\
R M S E=\frac{\sum_{i=1}^{n}\left(x_{i}-\hat{x}_{i}\right)^{2}}{n}
\end{array}
$$

In Equation (18) and Equation (19), values of ' $x_{\mathrm{i}}^{\prime}$ are the actual observed values, however, 'n' denoted for the number of predicted values, and $x_{i}$ are referred for the forecasted values.

\section{Estimations and Results}

\section{Exports and Imports Growth Rates}

Table 1 depicted the annual exports and imports growth rates from FY02-FY19, the results showed that maximum exports were recorded $\$ 25,171$ million in FY14, and maximum growth was seen $28.50 \%$ in FY11. However, the maximum imports were observed $\$ 55,169$ million in FY19, and in terms of maximum growth in imports, were recorded $38.76 \%$ in FY06. The alarming situation has been observed the continuous decline in exports from FY15 to FY17. Moreover, exports show a substantial increase in FY18 and a reduction in imports in the same year, which is encouraging for the policymakers and economic managers of the country. However, both exports and imports declined during FY19. The decline in exports is not recommended for any country which required revenues to meet the expenses and reduce the fiscal deficit. Still, on the other hand, substantial decline (-9.7 $\%$ in FY19) in imports reflects either the development process in the country probably shutdown or fiscal managers of the country are not economists.

\section{Augmented Dickey-Fuller and Philips-Perron Unit Root Tests}

The series must be stationary that is a prerequisite for applying time series models. The outcomes of ADF and Philips-Perron models are presented in Table 2, which demonstrates that LX and LM time series are non-stationary at level, thus, become stationary at first difference. Consequently, the integration of order for both data series is I(1).

\section{Graphical Representation of Stationary and Non-Stationary Series}

As exhibited by Figure 1, the first row graphs of both exports and imports data series exhibited the nonstationarity at a level. However, both data series became stationary at first difference, as depicted in the second row of Figure 1. Hence, Figure 1 is the confirmation of ADF

\begin{tabular}{|c|c|c|c|c|}
\hline \multirow{2}{*}{ Period } & \multicolumn{2}{|c|}{ Million USS } & \multicolumn{2}{|c|}{ Growth Rates } \\
\hline & Exports & Imports & Exports & Imports \\
\hline FY02 & 9,122 & 10,340 & & \\
\hline FY03 & 11,160 & 12,220 & 22.34 & 18.19 \\
\hline FY04 & 12,313 & 15,592 & 10.33 & 27.59 \\
\hline FY05 & 14,391 & 20,598 & 16.87 & 32.11 \\
\hline FY06 & 16,451 & 28,581 & 14.32 & 38.76 \\
\hline FY07 & 16,976 & 30,540 & 3.19 & 6.85 \\
\hline FY08 & 19,052 & 39,966 & 12.23 & 30.86 \\
\hline FY09 & 17,688 & 34,822 & -7.16 & -12.87 \\
\hline FY10 & 19,307 & 34,710 & 9.15 & -0.32 \\
\hline FY11 & 24,810 & 40,411 & 28.50 & 16.42 \\
\hline FY12 & 23,624 & 45,092 & -4.78 & 11.58 \\
\hline FY13 & 24,489 & 44,951 & 3.66 & -0.31 \\
\hline FY14 & 25,171 & 45,117 & 2.78 & 0.37 \\
\hline FY15 & 23,925 & 46,089 & -4.95 & 2.15 \\
\hline FY16 & 20,846 & 44,942 & -12.87 & -2.49 \\
\hline FY17 & 20,468 & 53,234 & -1.81 & 18.45 \\
\hline FY18 & 23,246 & 61,097 & 13.57 & 14.77 \\
\hline FY19 & 23,041 & 55,169 & -0.88 & -9.70 \\
\hline
\end{tabular}
and PP test results, which already demonstrated that the series is, integrated of order I(1).

Table 1

Annual Exports and Imports and Growth Rates 
Saghir Pervaiz Ghauri, Rizwan Raheem Ahmed, Dalia Streimikiene, Justas Streimikis. Forecasting Exports and Imports ...

Outcomes of Augmented Dickey-Fuller and Philips-Perron tests

Table 2

\begin{tabular}{llccccc}
\hline \multirow{2}{*}{ Variables } & \multicolumn{2}{c}{ Augmented Dickev-Fuller (ADF) } & \multicolumn{3}{c}{ Philips-Perron (PP) } \\
& Level & 1st Diff & Prob. & Level & 1st Diff & Prob. \\
\hline LExport & -3.0271 & -5.0228 & $*$ & -2.3802 & -25.3417 & $*$ \\
LImport & -2.1839 & -14.7194 & $*$ & -2.2766 & -31.8901 & $*$ \\
\hline
\end{tabular}

Note: *significant at 0.01 significance level. MacKinnon (1991) critical value (-3.461 at 0.01), and rejected the unit root hypothesis Source: Authors' calculations
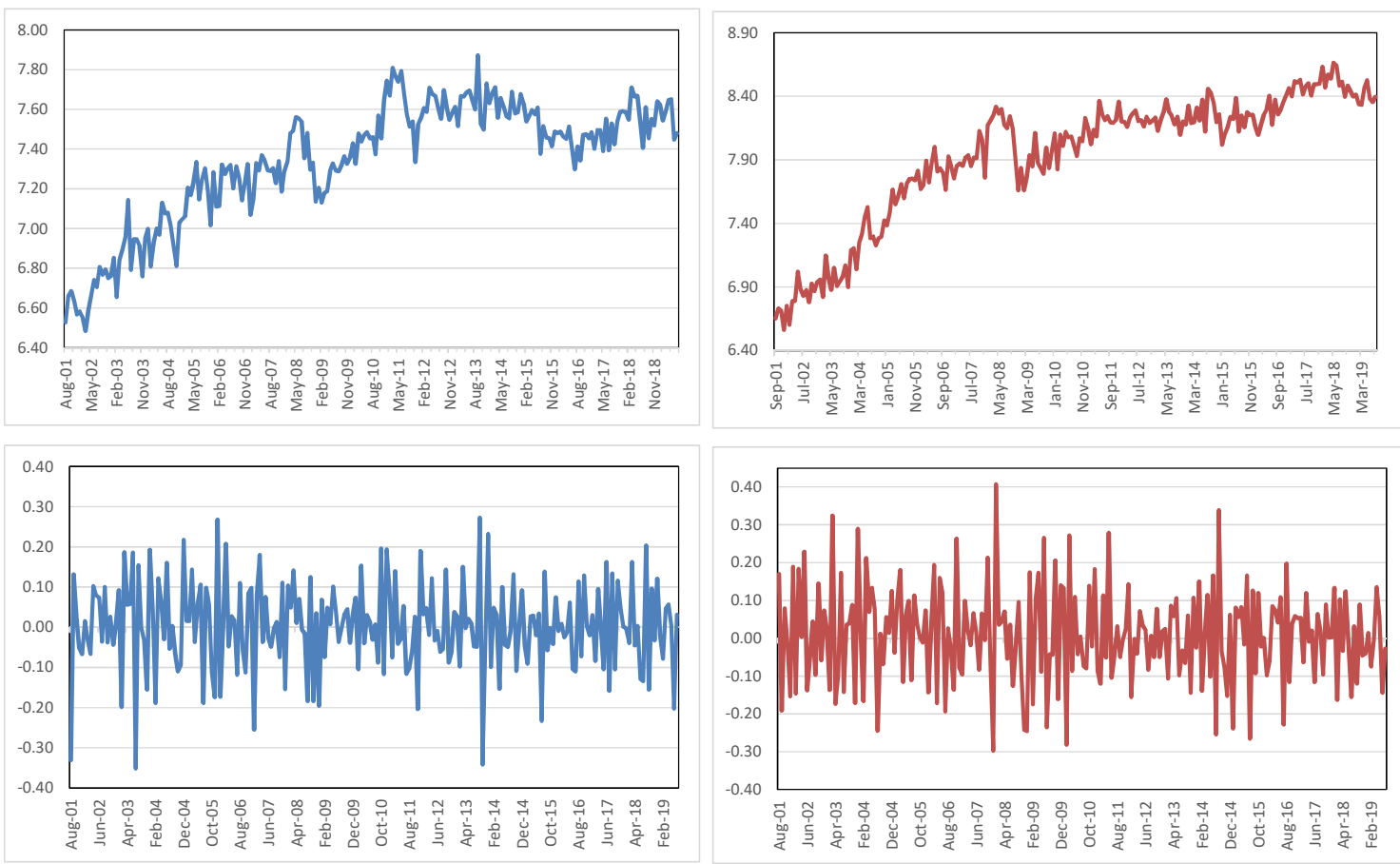

Figure 1. Pakistan's Exports \& Imports from FY02-FY19 (in Log form) - Non-Stationary and Stationary series Source: Authors' calculations

\section{Autoregressive (AR) Model with Seasonal Dummies}

Since both series are I(1), so we apply the AR model with seasonal dummies to both series on a different set. DLX exhibited the $1^{\text {st }}$ difference of natural log of exports, whereas, DLM demonstrated the $1^{\text {st }}$ difference of natural log of imports. We use all eleven seasonal dummies initially and exclude all those dummies, which are not statistically significant. We generally apply to a specific approach for the identification of autoregressive processes. We estimated different AR models by using a maximum of 12 autoregressive methods, the final model is obtained by eliminated the statistically not significant AR processes. The model models are presented below. In both DLX \& DLM models, the significant AR processes are 2 means both DLX \& DLM are dependent on the previous two-month observations. This can quickly be explained, as every month, the commodities exported or imported are not changed frequently. Table 3 and Table 4 have displayed detailed outcomes; the estimated model of DLX is expressed as follows:

$$
\begin{aligned}
& D L X_{t}=0.041-0.565 D L X_{t-1}-0.163 D L X_{t-2}- \\
& 0.074 @ \operatorname{seas}(2)-0.124 @ \operatorname{seas}(7)-0.057 @ \\
& \operatorname{seas}(8)-0.060 @ \operatorname{seas}(10)-0.097 @ \operatorname{seas}(11)
\end{aligned}
$$

Since, $\mathrm{R}^{2}$ : 0.40 , which shows that input explained 0.40 of output, and Durbin Watson statistics: 1.91, since the DW value is less than 2 . Thus this implies that there is positive autocorrelation, which is evidence of positive serial correlation. The estimated model of DLM is exhibited as:

$$
D L M_{t}=0.003-0.541 D L M_{t-1}-0.167 D L M_{t-2}-
$$$$
\text { 0.058@seas }(2)+0.077 @ \operatorname{seas}(3)+0.057 @ \operatorname{seas}(4)
$$$$
\text { +0.081@seas(5)+0.063@seas(6)-0.098@seas }(7)
$$

Since, $\mathrm{R}^{2}: 0.40$, which shows that input explained 0.40 of output, and Durbin Watson statistics: 2.02, since the DW value is less than 2 . Thus this implies that there is positive autocorrelation, which is evidence of positive serial correlation.

\section{ARIMA Technique}

Same as of AR model, approach for the identification of both autoregressive processes (p) and moving average $(q)$ 
ARIMA model is applied. We initially estimated different ARIMA models by using a maximum of 11 of both $p \& q$ processes. The final model is obtained by eliminated the statistically not significant of both $p \& q$ processes. The estimated ARIMA model for exports is ARIMA $(7,1,8)$, detailed outcomes of the models are displayed in Table 5. Results of Table 5 exhibit that a number of Auto-regressive terms are 7; however, a single non-seasonal difference is required for the stationarity with eight lagged periods forecasting errors in the prediction equation for exports.

The estimated ARIMA model for imports is ARIMA $(8,1,5)$, as depicted in Table 6 . Thus, for the imports, there are 8 numbers of Auto-regressive terms for a single non-seasonal difference for the stationarity with five lagged periods forecasting errors for the predicting equation of imports.

\section{Forecasted Values of Exports and Imports}

Forecasted values of exports and imports for the FY20 are reported in Table 7. Autoregressive (AR) with seasonal dummies model have forecasted the exports and imports for the FY20, according to this model, the forecasted values for exports are $\$ 21,929$ million with the negative variation of -
$4.83 \%$, and imports are $\$ 54,279$ million with the negative change of $-1.61 \%$. However, according to the ARIMA model, the forecasted values for exports are $\$ 23,471$ million, with a positive growth of $1.87 \%$, and imports are $\$ 58,961$ million with a positive growth of $6.87 \%$.

\section{Forecasting Errors}

Table 7 demonstrated the outcomes of forecasting errors of RMSE and MAE techniques. RMSE for exports is 0.113 , and for imports is 0.096 , whereas MAE for exports is 0.091, and for imports is 0.070 for the Autoregressive (AR) with seasonal dummies model. Similarly, RMSE of exports is 0.106 , and for imports is 0.099 , whereas MAE for exports is 0.083 , and for imports is 0.087 for the ARIMA model. Since we have the least forecasting errors of both RMSE \& MAE for both imports in the AR model with seasonal dummies and on the other hand, for exports in the ARIMA model have minimum values of both RMSE \& MAE. Therefore, the projected growth of exports is 1.87 percent, and forecasted growth in imports is -1.61 percent in FY20 as compared to FY19.

Table 3

AR Model with Seasonal Dummies: Dependent Variable - DLX

\begin{tabular}{|c|c|c|c|c|}
\hline Variable & Coefficient & Std. Error & t-Statistic & Prob. \\
\hline $\mathrm{C}$ & 0.0412 & 0.0077 & 5.3797 & 0.0000 \\
\hline $\operatorname{DLX}(-1)$ & -0.5646 & 0.0648 & -8.7082 & 0.0000 \\
\hline $\operatorname{DLX}(-2)$ & -0.1630 & 0.0618 & -2.6376 & 0.0090 \\
\hline (a)SEAS(2) & -0.0741 & 0.0219 & -3.3874 & 0.0008 \\
\hline @SEAS(7) & -0.1237 & 0.0220 & -5.6134 & 0.0000 \\
\hline @SEAS(8) & -0.0567 & 0.0230 & -2.4656 & 0.0145 \\
\hline @SEAS(10) & -0.0596 & 0.0214 & -2.7930 & 0.0057 \\
\hline @SEAS(11) & -0.0971 & 0.0215 & -4.5251 & 0.0000 \\
\hline R-squared & 0.4004 & Mean dependent var & & 0.0037 \\
\hline Adjusted R-squared & 0.3799 & S.D. dependent var & & 0.1071 \\
\hline S.E. of regression & 0.0844 & Akaike info criterion & & -2.0705 \\
\hline Sum squared resid & 1.4590 & Schwarz criterion & & -1.9443 \\
\hline Log-likelihood & 228.51 & Hannan-Quinn criter. & & -2.0195 \\
\hline F-statistic & 19.56 & Durbin-Watson stat & & 1.9069 \\
\hline Prob(F-statistic) & 0.0000 & & & \\
\hline
\end{tabular}

Source: Authors' calculations

Table 4

AR Model with Seasonal Dummies: Dependent Variable - DLM

\begin{tabular}{|c|c|c|c|c|}
\hline Variable & Coefficient & Std. Error & t-Statistic & Prob. \\
\hline $\mathrm{C}$ & 0.0030 & 0.0097 & 0.3110 & 0.7561 \\
\hline $\operatorname{DLM}(-1)$ & -0.5410 & 0.0670 & -8.0750 & 0.0000 \\
\hline $\operatorname{DLM}(-2)$ & -0.1674 & 0.0662 & -2.5277 & 0.0122 \\
\hline (a) $\operatorname{SEAS}(2)$ & -0.0578 & 0.0256 & -2.2568 & 0.0251 \\
\hline (a)SEAS(3) & 0.0767 & 0.0255 & 3.0021 & 0.0030 \\
\hline (a)SEAS(4) & 0.0574 & 0.0264 & 2.1749 & 0.0308 \\
\hline (a)SEAS(5) & 0.0809 & 0.0269 & 3.0077 & 0.0030 \\
\hline (a)SEAS(6) & 0.0631 & 0.0260 & 2.4318 & 0.0159 \\
\hline (a)SEAS(7) & -0.0983 & 0.0269 & -3.6501 & 0.0003 \\
\hline R-squared & 0.4047 & Mean dependent var & & 0.0081 \\
\hline Adjusted R-squared & 0.3813 & S.D. dependent var & & 0.1263 \\
\hline S.E. of regression & 0.0993 & Akaike info criterion & & -1.7397 \\
\hline Sum squared resid & 2.0122 & Schwarz criterion & & -1.5977 \\
\hline Log-likelihood & 194.28 & Hannan-Quinn criter. & & -1.6823 \\
\hline F-statistic & 17.33 & Durbin-Watson stat & & 2.0175 \\
\hline Prob(F-statistic) & 0.0000 & & & \\
\hline
\end{tabular}

Source: Authors' calculations 
Saghir Pervaiz Ghauri, Rizwan Raheem Ahmed, Dalia Streimikiene, Justas Streimikis. Forecasting Exports and Imports ...

Box Jenkins or ARIMA (7,1,8) for Export Results

\begin{tabular}{|c|c|c|c|c|}
\hline Variable & Coefficient & Std. Error & t-Statistic & Prob. \\
\hline $\mathrm{C}$ & 0.0041 & 0.0029 & 1.4074 & 0.1609 \\
\hline $\operatorname{AR}(1)$ & -0.3883 & 0.0623 & -6.2376 & 0.0000 \\
\hline $\operatorname{AR}(2)$ & -0.6642 & 0.0623 & -10.6562 & 0.0000 \\
\hline $\operatorname{AR}(5)$ & -0.5859 & 0.0630 & -9.3021 & 0.0000 \\
\hline $\operatorname{AR}(6)$ & -0.3497 & 0.0627 & -5.5795 & 0.0000 \\
\hline $\operatorname{AR}(7)$ & -0.8650 & 0.0532 & -16.2444 & 0.0000 \\
\hline MA(1) & -0.2519 & 0.1174 & -2.1453 & 0.0331 \\
\hline $\mathrm{MA}(2)$ & 0.5337 & 0.1186 & 4.4997 & 0.0000 \\
\hline MA(3) & -0.2174 & 0.1017 & -2.1378 & 0.0337 \\
\hline MA(5) & 0.7052 & 0.1550 & 4.5497 & 0.0000 \\
\hline MA(6) & -0.1747 & 0.0897 & -1.9473 & 0.0529 \\
\hline $\operatorname{MA}(7)$ & 0.6408 & 0.2185 & 2.9332 & 0.0037 \\
\hline $\mathrm{MA}(8)$ & -0.4823 & 0.2147 & -2.2463 & 0.0258 \\
\hline SIGMASQ & 0.0068 & 0.0007 & 9.4398 & 0.0000 \\
\hline R-squared & 0.4284 & Mean dependent var & & 0.0027 \\
\hline Adjusted R-squared & 0.3915 & S.D. dependent var & & 0.1094 \\
\hline S.E. of regression & 0.0853 & Akaike info criterion & & -1.9961 \\
\hline Sum squared resid & 1.4640 & Schwarz criterion & & -1.7766 \\
\hline Log-likelihood & 228.58 & Hannan-Quinn criter. & & -1.9074 \\
\hline F-statistic & 11.59 & Durbin-Watson stat & & 1.8582 \\
\hline Prob(F-statistic) & 0.0000 & & & \\
\hline
\end{tabular}

Source: Authors' calculations

Table 6

Box Jenkins or ARIMA $(8,1,5)$ for Import Results

\begin{tabular}{|c|c|c|c|c|}
\hline Variable & Coefficient & Std. Error & t-Statistic & Prob. \\
\hline $\mathrm{C}$ & 0.0080 & 0.0035 & 2.3099 & 0.0219 \\
\hline $\mathrm{AR}(1)$ & -0.4680 & 0.0585 & -8.0032 & 0.0000 \\
\hline $\mathrm{AR}(2)$ & -0.1153 & 0.0609 & -1.8927 & 0.0598 \\
\hline $\mathrm{AR}(4)$ & -0.4544 & 0.1188 & -3.8244 & 0.0002 \\
\hline $\mathrm{AR}(5)$ & 0.2690 & 0.1293 & 2.0798 & 0.0388 \\
\hline $\operatorname{AR}(6)$ & 0.2602 & 0.0819 & 3.1765 & 0.0017 \\
\hline $\operatorname{AR}(7)$ & 0.1695 & 0.0733 & 2.3124 & 0.0218 \\
\hline $\mathrm{AR}(8)$ & -0.1906 & 0.0650 & -2.9299 & 0.0038 \\
\hline $\mathrm{MA}(4)$ & 0.3583 & 0.0820 & 4.3719 & 0.0000 \\
\hline MA(5) & -0.6502 & 0.0928 & -7.0035 & 0.0000 \\
\hline SIGMASQ & 0.0102 & 0.0010 & 9.9028 & 0.0000 \\
\hline R-squared & 0.3636 & Mean dependent var & & 0.0079 \\
\hline Adjusted R-squared & 0.3324 & S.D. dependent var & & 0.1269 \\
\hline S.E. of regression & 0.1037 & Akaike info criterion & & -1.6262 \\
\hline Sum squared resid & 2.1932 & Schwarz criterion & & -1.4537 \\
\hline Log-likelihood & 185.81 & Hannan-Quinn criter. & & -1.5565 \\
\hline F-statistic & 11.65 & Durbin-Watson stat & & 1.9669 \\
\hline Prob(F-statistic) & 0.0000 & & & \\
\hline
\end{tabular}

Source: Authors' calculations

Table 7

Forecasted Values and Growth Rates for FY20

\begin{tabular}{|c|c|c|c|c|c|c|c|c|}
\hline & Million US\$ & & Growth rates & & RMSE & & MAE & \\
\hline & Exports & Imports & Exports & Imports & Exports & Imports & Exports & Imports \\
\hline \multicolumn{9}{|c|}{ (Using AR with seasonal dummies model) } \\
\hline FY20 & 21,929 & 54,279 & -4.83 & -1.61 & 0.133 & 0.096 & 0.091 & 0.070 \\
\hline \multicolumn{9}{|c|}{ (Using ARIMA model) } \\
\hline FY20 & 23,471 & 58,961 & 1.87 & 6.87 & 0.106 & 0.099 & 0.083 & 0.087 \\
\hline
\end{tabular}

Source: Authors' calculations 


\section{Conclusions}

The outcomes of the undertaken research exhibited the efficiencies of both time series techniques, besides specific results of forecasting of exports and imports for the FY2020 lay down the foundations for appropriate policymaking by the government of Pakistan. According to the outcomes, the ARIMA or Box Jenkins techniques exhibit the best forecasting values of exports due to the value of MAE, which is the least as compared to the AR model with seasonal dummies. However, for the forecasting of imports, the AR model with dummies is preferable. This study also demonstrated that for any robust forecasting, the ARIMA approach offers a reliable technique that is projecting any extent of a time-varying factor. There are several strengths of the ARIMA models, such as this model could be used as low as 50 observations besides the unlimited observations; however, this model could be used for any time series data with several patterns of changes. It should be kept in mind that any proper forecasting technique for any particular situation may become unsuitable for diverse conditions, thus the validation should be examined for any specific model. The exports are vital for the progress of a developing country, especially countries like Pakistan, that is already going through a vulnerable economic situation such as almost all the macroeconomic indicators show negative variation. The findings of the undertaken study recommend to the policymakers of Pakistan to take corrective measures to increase exports and to prevent the country from the negative trade balance that will also negatively influence the supply and demand-side factors. The government of Pakistan should give more incentives to the exporters and decrease the cost of doing business to remain competitive than other regional economies such as Bangladesh, India, and China. The findings of the undertaken study suggest to the future research studies that these models can be employed for the forecasting of imports and exports. Still, the data should be updated in terms of current numbers and more accuracy. It is recommended to the researchers that they should follow the principle of parsimony to fit a simple model instead of complicated and broad parameters. However, there are certain limitations of these models. Thus, it is recommended to the future studies that they should use a general equilibrium model, Bayesian artificial neural networks or artificial neural network model for more comprehensive results.

\section{Disclosure Statement}

The authors have not reported any hindering conflict of interest.

\section{References}

Ahmed, R. R., Ghauri, S. P., Vveinhardt, J., \& Streimikiene, D. (2018). An Empirical analysis of Export, Import, and Inflation: A Case of Pakistan. Romanian Journal of Economic Forecasting, 21(3), 117-130.

Alam, M. M., Uddin, M. G. S., \& Taufique, K. M. R. (2009). Import flows of Bangladesh: the gravity model approach. International Journal of Economics and Finance, 1(1), 131-140. https://doi.org/10.5539/ijef.v1n1p131

Alam, T. (2019). Forecasting exports and imports through artificial neural network and autoregressive integrated moving average. Decision Science Letters, 8, 249-260. https://doi.org/10.5267/j.ds1.2019.2.001

Anderton, R., Baltagi, B. H., Skudelni, F., \& Sousa, N. (2005). Intra- and Extra-Euro Area Import Demand for Manufactures, European Central Bank Working Paper Series, No. 532. Available online: https://www.ecb.europa.eu/ pub/pdf/scpwps/ecbwp532.pdf

Azgun, S., \& Servinc, H. (2010). Are imports a reason of growth? evidence from Turkey. The Social Sciences, 5(2), 6669. https://doi.org/10.3923/sscience.2010.66.69

Box, G. E. P., \& Jenkins, G. M (1976). Time series analysis in forecasting and control applied statistics. Holden-Day, San Francisco.

Box, G. E. P., Jenkins, G. M., \& Reinsel, G. C. (1994). Time Series Analysis: Forecasting and Control, 3rd edition, Prentice Hall, Englewood Cliffs, New Jersey.

Chen, H. (2009). A literature review on the relationship between foreign trade and economic growth. International Journal of Economics and Finance, 1(1), 127-30. https://doi.org/10.5539/ijef.v1n1p127

Chou, C. C., Chu, C. W., \& Liang, G. S. (2008). A modified regression model for forecasting the volumes of Taiwan's import containers. Mathematical and Computer Modelling, 47(9), 797-807. https://doi.org/10.1016/ j.mcm.2007.05.005

Dickey, D. A., \& Fuller, W. A. (1979). Distribution of estimators for autoregressive time series with a unit root. Journal of the American Statistical Association, 74 (366a), 427-431. https://doi.org/10.1080/01621459.1979.10482531

Dickey, D. A., \& Fuller, W. A. (1981). Likelihood ratio statistics for autoregressive time series with a unit root. Econometrica, 49(4), 1057-1072. https://doi.org/10.2307/1912517

Đokovic, J., Muncan, M., \& Paunovic, T. (2019). Forecasting maize yield in the Republic of Serbia by using Box-Jenkins methodology. Ekonomika poljoprivrede, 66(2), 525-540. https://doi.org/10.5937/ekoPolj1902525D 
Saghir Pervaiz Ghauri, Rizwan Raheem Ahmed, Dalia Streimikiene, Justas Streimikis. Forecasting Exports and Imports ...

Ersen, N., Akyuz, I., \& Bayram, B. C. (2019). The forecasting of the exports and imports of paper and paper products of Turkey using Box-Jenkins method. Eurasian Journal of Forest Science, 7(1), 54-65. https://doi.org/10. 31195/ejejfs.502397

Farinelli, B., Carter, C. A., Cynthia-Lin, C. Y., \& Sumner, D. A. (2009). Import demand for Brazilian ethanol: a crosscountry analysis. Journal of Cleaner Production, 17(1), S9- S17. https://doi.org/10.1016/j.jclepro.2009.05.008

Fukumoto, M. (2012). Estimation of China's disaggregated import demand functions. China Economic Review, 23(2), 434444. https://doi.org/10.1016/j.chieco.2012.03.002

Ghafoor, A., Abedullah., Khokhar, S. B., \& Hanif, S. (2005). Import demand function of wheat and future trends. Journal of Agriculture and Social Sciences, 1(4), 350-354.

Kankal, M., \& Uzlu, E. (2017). Neural Network Approach with Teaching-Learning-Based Optimization for Modeling and Forecasting Long-Term Electric Energy Demand in Turkey. Neural Computing and Applications, 28(1), $737-747$. https://doi.org/10.1007/s00521-016-2409-2

Kargbo, J. M. (2007). Forecasting agricultural exports and imports in South Africa. Applied Economics, 39(16), 20692084. https://doi.org/10.1080/00036840600707183

Kaur, S., \& Rakshit, M. (2019). Seasonal and periodic Autoregressive time series models used for forecasting analysis of Rainfall data. International Journal of Advanced Research in Engineering \& Technology, 10(1). https://doi.org/10. 34218/IJARET.10.1.2019.023

Keck, A., Raubold, A., \& Truppia, A. (2009). Forecasting International Trade: A Time Series Approach. OECD Journal: Journal of Business Cycle Measurement and Analysis, 9(2), 157-176. https://doi.org/10.1787/jbcma-2009$5 \mathrm{ks} 9 \mathrm{v} 44 \mathrm{bdj} 32$

Khan, T. (2011). Identifying an Appropriate Forecasting Model for Forecasting Total Import of Bangladesh. International Journal of Trade, Economics and Finance, 2(3), 242-246. https://doi.org/10.7763/IJTEF.2011.V2.109

Kitworawut, P., \& Rungreunganun, V. (2019). Corn Price Modeling and Forecasting Using Box-Jenkins Model. Applied Science and Engineering Progress. https://doi.org/10.14416/j.asep.2019.02.007

Kogid, M., Mulok, D., Ching, K. S., Lily, J., Ghazali, M. F., \& Loganathan, N. (2011). Does Import Affect Economic Growth in Malaysia. The Empirical Economics Letters, 10 (3), 297- 307.

Mehmood, A., Sial, M. H., Sharif, S., Hussain, A., Riaz, M., \& Shaheen, N. (2020). Forecasting the Fisheries Production in Pakistan for the Year 2017-2026, using Box-Jenkin's Methodology. Pakistan Journal of Agricultural Research, 33(1). https://doi.org/10.17582/journal.pjar/2020/33.1.140.145

Mladenovic, J., Lepojevi, V., \& VJankovi-Milic, (2016). Modelling and Prognosis of the Export of the Republic of Serbia by Using Seasonal Holt-Winters and ARIMA Method (De Gruyter). Economic Theme, 54(2), $233-260$. https://doi.org/10.1515/ethemes-2016-0012

Narayan, P. K., Narayan, S., \& Prasad, B. C. (2008). Forecasting Fiji's exports and imports, 2003-2020. International journal of social economics, 35(12), 1005-1016. https://doi.org/10.1108/03068290810911516

Phillips, P. C. B., \& Hansen, B. E. (1990). Statistical Inference in Instrumental Variables Regression with I(1) Processes. The Review of Economic Studies, 57(1), 99-125. https://doi.org/10.2307/2297545

Phillips, P. C. B., \& Perron, P. (1988). Testing for a Unit Root in Time Series Regression. Biometrika, 75(2), 335-346. https://doi.org/10.1093/biomet/75.2.335

Sahu, P. K., \& Mishra, P. (2013). Modelling and Forecasting Production Behaviour and Import-Export of total Spices in two most Populous Countries of the World. Journal of Agricultural Research, 51(1), 81-97.

Sharma, R. K. (2019). Forecasting Volatility of Crude oil Prices using Box-Jenkins's Autoregressive Moving Average: Evidence from Indian Chemical Industry. International Journal of Recent Technology and Engineering, 8(3), 229234. https://doi.org/10.35940/ijrte.C3948.098319

Shu, M. H., Nguyen, T. L., Hsu, B.M., Lu, C., \& Huang, J. C. (2014). Forecasting Cargo Throughput with Modified Seasonal ARIMA Models. WSEAS Transactions on Mathematics, 13, 171-181.

Sokolov-Mladenovic, S., Milovancevic, M., Mladenovic, I., \& Alizamir, M. (2016). Economic Growth Forecasting by Artificial Neural Network with Extreme Learning Machine Based on Trade, İmport and Export Parameters. Computers in Human Behavior, 65, 43-45. https://doi.org/10.1016/j.chb.2016.08.014

Tabrizi, S. S., \& Sancar, N. (2017). Prediction of Body Mass Index: A Comparative Study of Multiple Linear Regression, ANN and ANFIS Models. Procedia Computer Science, 120, 394-401. https://doi.org/10.1016/j.procs.2017.11.255 
Urrutia, J. D., Abdul, A. M., \& Atienza, J. B. E. (2019). Forecasting Philippines imports and exports using Bayesian artificial neural network and autoregressive integrated moving average. AIP Conference Proceedings 2192, 090015 (December 19). https://doi.org/10.1063/1.5139185

Wang, W. C., Chau, K. W., Xu, D. M., \& Chen, X. Y. (2015). Improving forecasting accuracy of annual runoff time series using ARIMA based on EEMD decomposition. Water Resources Management, 29(8), $2655-2675$. https://doi.org/10.1007/s11269-015-0962-6

Wong, H. T. (2004). Terms of trade and economic growth in Malaysia. Labuan Bulletin of International Business and Finance, 2(2), 105-122.

Yucesan, Y., Gul, M., \& Celik, E. (2017). Application of ANN using Bayesian Training Rules in Sales Forecasting for Furniture Industry. DRVNA INDUSTRIJA, 68(3), 219-228. https://doi.org/10.5552/drind.2017.1706

Yue, Y. (2010). An Econometric Estimation of Import Demand Function for Cote D'Ivoire. International Journal of Business and Management, 5(2), 77-84. https://doi.org/10.5539/ijbm.v5n2p77

Zeng, Y. R., Zeng, Y., Choi, B., \& Wang, L. (2017). Multifactor-influenced energy consumption forecasting using enhanced back-propagation neural network. Energy, 127, 381-396. https://doi.org/10.1016/j.energy.2017.03.094

Zhang, W., \& Zhao, S. (2013). Forecasting Research on the Total Volume of Import and Export Trade of Ningbo Port by Gray Forecasting Model. Journal of Software, 8(2), 466-471. https://doi.org/10.4304/jsw.8.2.466-471

Zhou, Z. B., \& Dong, X. C. (2012). Analysis about the seasonality of China's crude oil import based on X-12-ARIMA. Energy, 42(1), 281-288. https://doi.org/10.1016/j.energy.2012.03.058

The article has been reviewed.

Received in February 2020; accepted in June 2020. 